wachting zonder chronische ziekte afneemt. ${ }^{3,4}$ Zo is het aantal jaar dat mensen doorbrengen zonder een chronische aandoening afgenomen van ruim 50 jaar begin jaren tachtig tot ongeveer 45 jaar nu. Dit betekent dus dat het aantal jaar met ziekte toeneemt en er meer mensen een chronische ziekte hebben. Gemiddeld leven Nederlanders nu 45 jaar zonder en 35 jaar met een chronische ziekte. Deze ziektejaren treden vooral, maar niet uitsluitend, op hogere leeftijd op. Op 65-jarige leeftijd hebben zowel mannen als vrouwen gemiddeld genomen nog zo'n vier jaar zonder ziekte voor de boeg.

\section{CHRONISCH ZIEK EN LANGER DOORWERKEN}

Een chronische ziekte hebben betekent nog niet chronisch ziek zijn. Er zijn genoeg voorbeelden van mensen die een chronische ziekte onder de leden hebben, terwijl ze meer dan volledig arbeidsproductief zijn. Gemiddeld genomen echter, zijn er wel degelijk minder chronisch zieken met een baan dan mensen zonder ziekte. Zo heeft de helft van de gezonde werknemers van 55 tot 65 jaar een betaalde baan tegenover een derde van de chronisch zieke oudere werknemers. ${ }^{5}$ Het merendeel van de mensen met een ziekte wil wel graag aan het werk. Drempels die zij noemen zijn slecht vervoer, discriminatie en te weinig aanpassingen op de werkvloer. ${ }^{6}$

\section{ANDERE VORMEN VAN PARTICIPATIE OOK VAN BELANG}

Het verrichten van betaalde arbeid is een belangrijke vorm van meedoen in onze samenleving. Niet alleen voor het inkomen, maar minstens zoveel omdat werken sociale contacten en zingeving met zich meebrengt. Het is echter de vraag of alleen betaald werk het antwoord is op deze behoeften. Veel ouderen doen op tal van andere manieren mee in de maatschappij. Zo doet een groot deel aan vrijwilligerswerk en mantelzorg. Deze aspecten zijn net als betaalde arbeid niet alleen goed voor de ouderen zelf, maar ook voor de maatschappij. Daarnaast zijn er ook meer persoonlijke vormen van participatie, zoals deelname aan recreatieve en culturele activiteiten. Deze betrokkenheid bij de samenleving is niet alleen cruciaal voor persoonlijk welzijn, mar ook voor het 'weefsel van de samenleving'. Kortom, de aanname dat "ouderen bij hun pensionering staan voor een steeds langere periode waarin zij in goede gezondheid geen maatschappelijke prestatie meer leveren en waarin ze zelf ook geen bevrediging meer kunnen halen uit de veelheid aan sociale contacten, uit hulp aan anderen en aan de productie van nuttige zaken die samenhangen met betaald werk"7 behoeft enige nuancering. Het is immers niet zo duidelijk of ouderen inderdaad een steeds langere periode in goede gezondheid voor zich hebben. Bovendien kan niet alleen betaalde arbeid voor deze bevrediging zorgen.

\section{CONCLUSIE}

Verhoging van de arbeidsparticipatie in de wetenschap dat Nederland meer chronisch zieken telt, vereist een beleid dat gericht is op het scheppen van betere kansen voor mensen met een chronische ziekte om aan het arbeidsproces te kunnen deelnemen. Vanuit het volksgezondheidsbeleid gaat het dan niet alleen om de preventie van ziekte, maar ook om het scheppen van de juiste voorwaarden voor hen die niet optimaal gezond zijn. Dit laatste is betreft niet alleen het ministerie van VWS, maar zeker ook dat van SZW en de werkgevers. Bovendien zijn er parallellen tussen arbeid en onderwijs. Deelname op de arbeidsmarkt begint immers bij goede scholing.

\section{LITERATUUR}

1. Vrijheid en verantwoordelijkheid. Regeerakkoord VVD-CDA, 2010.

2. CBS-statline, geraadpleegd op 16-12-2010.

3. Lucht F van der, Polder JJ. Van gezond naar beter. Kernrapport van de Volksgezondheid Toekomst Verkenning 2010. Houten: Bohn Stafleu van Loghum, 2010.

4. Hoeymans N, Melse JM, Schoemaker CG. Gezondheid en determinanten. Deelrapport van de Volksgezondheid Toekomst Verkenning 2010. Houten: Bohn Stafleu van Loghum, 2010.

5. Hoeymans $N$. Maatschappelijke participatie bij ouderen. TPEdigitaal 2009;3(2): 53-66.

6. Brink-Muinen A van den, Rijken PM, Spreeuwenberg $P$, Heijmans MWJM. Kerngegevens maatschappelijke situatie 2008. Nationaal Panel Chronisch Zieken en Gehandicapten. Utrecht: NIVEL, 2009.

7. Commissie Bakker. Naar een toekomst die werkt. Advies Commissie Arbeidsparticipatie, 2008.

\section{CORRESPONDENTIEADRES}

Dr. N. Hoeymans, centrum Volksgezondheid Toekomst Verkenningen, RIVM, Postbus 1, 3720 BA, Bilthoven, e-mail: Nancy.Hoeymans@rivm.nl

\title{
Willen we langer doorwerken?
}

\author{
Jan Fekke Ybema, ${ }^{1}$ Goedele Geuskens ${ }^{1}$
}

In de discussie over langer doorwerken is het van groot belang om te weten hoe werknemers daar zelf tegen aankijken. Willen oudere werknemers wel langer doorwerken dan tot nu toe gebruikelijk is? Geen werkgever zit immers te wachten op onge- motiveerde werknemers die de tijd tot hun pensioen uitzitten. Omdat slechts een klein deel van de oudere werknemers op dit moment doorwerkt tot de huidige pensioenleeftijd (65 jaar), richten we ons hier op doorwerken tot het vijfenzestigste levensjaar.

1 TNO, Hoofddorp 
Wilt u tot uw 65e werkzaam blijven?

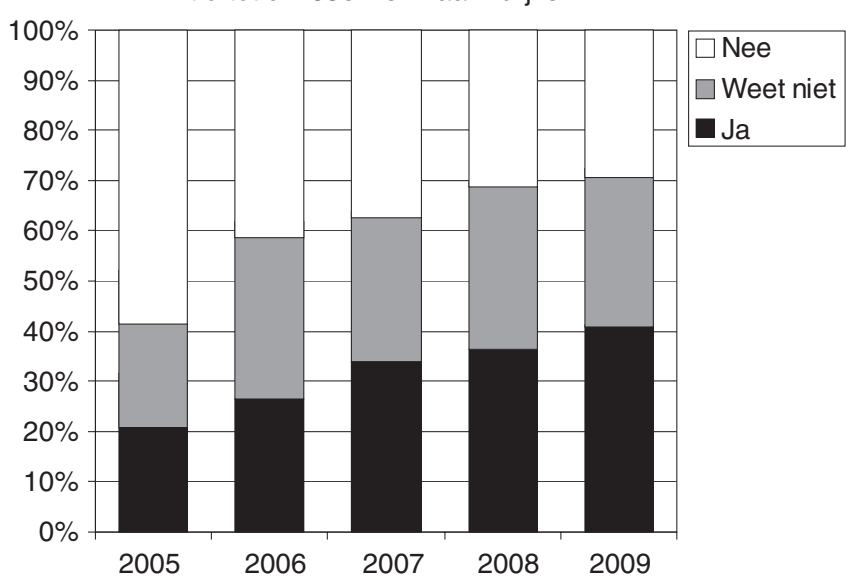

Figuur 1 Het percentage werknemers van 45 tot 64 jaar dat wil doorwerken tot hun vijfenzestigste levensjaar (Bron: NEA ${ }^{1}$ ).

TRENDS IN DE MOTIVATIE OM TOT HET VIJFENZESTIGSTE LEVENSJAAR TE WERKEN

In de figuur 1 is weergegeven welk deel van de werknemers van 45 tot 64 jaar in Nederland wil doorwerken tot hun vijfenzestigste en hoe dit zich heeft ontwikkeld tussen 2005 en 2009. We zien een spectaculaire toename in het percentage werknemers dat wil doorwerken tot ze 65 zijn. Dit verdubbelt van $21 \%$ in 2005 tot $42 \%$ in 2009 . Het percentage werknemers dat niet tot hun vijfenzestigste wil doorwerken neemt daarbij af van $57 \%$ in 2005 tot $40 \%$ in 2009 , terwijl het percentage dat het niet weet steeds rond de $20 \%$ schommelt.

Waar komt die sterke toename in motivatie om langer door te werken vandaan? Ongetwijfeld heeft de toename te maken met de maatschappelijke discussie over langer doorwerken die in de afgelopen jaren is gevoerd. Door de ophef over het verhogen van de pensioenleeftijd ("65 blijft 65 ") vergeten veel werknemers wellicht dat de grote meerderheid in de afgelopen decennia ruim voor hun vijfenzestigste stopte met werken. Hierdoor verandert de referentieleeftijd voor vervroegd uittreden van bijvoorbeeld 60 naar 65 jaar. Daarnaast is het in de afgelopen jaren financieel gezien steeds minder aantrekkelijk geworden om vervroegd uit te treden, bijvoorbeeld door de hervorming van de VUT-regeling naar het Prepensioen.

\section{WIE WILLEN ER LANGER DOORWERKEN?}

Waarin verschillen mensen die wel willen doorwerken tot hun vijfenzestigste van mensen die dat niet willen? Uit ons onderzoek blijkt dat mensen met een hoge opleiding vaker willen doorwerken tot hun vijfenzestigste dan mensen met een lage of een middelbare opleiding. ${ }^{2}$ Verder willen werknemers in de bouw duidelijk het minst vaak doorwerken tot hun vijfenzestigste, op afstand gevolgd door werknemers in de industrie, de financiële dienstverlening en het openbaar bestuur (overheid). Werknemers in de culturele dienstverlening, in de landbouw en de zakelijke dienstverlening willen juist vaker dan gemiddeld doorwerken tot hun vijfenzestigste. Het lijkt erop dat werknemers met een lichamelijk zwaar beroep minder vaak tot hun vijfenzestigste willen doorwerken dan werknemers die geen lichamelijk zwaar beroep hebben, al gaat dit niet op voor werknemers met een agrarisch beroep. Verder is het opvallend dat werknemers met een psychisch zwaar beroep, in de zorg en het onderwijs, iets vaker tot hun vijfenzestigste willen doorwerken dan gemiddeld. Overigens vinden we dat zowel werknemers met lichamelijk als met psychisch zware beroepen relatief vaak aangeven dat ze niet tot hun vijfenzestigste kunnen doorwerken in hun huidige beroep.

\section{WAT VOORSPELT OF WERKNEMERS WILLEN DOORWERKEN?}

Mannen en werknemers van 60 tot 63 jaar willen vaker doorwerken tot het vijfenzestigste levensjaar dan vrouwen en werknemers jonger dan 60. Dat vooral werknemers van 60-63 jaar willen doorwerken komt deels doordat zij anders al eerder waren gestopt. Ook het sociale klimaat op het werk beïnvloedt de motivatie om tot het vijfenzestigste levensjaar door te werken. Pesten, intimidatie, ongewenste seksuele aandacht of geweld door collega's of de leidinggevende voorspelt dat werknemers minder vaak willen doorwerken. Tot slot is gezondheid van voorspellende waarde: werknemers die uitputting door het werk (burnout) ervaren, willen minder vaak doorwerken tot hun vijfenzestigste. Kortom, om te bevorderen dat werknemers willen doorwerken tot het vijfenzestigste levensjaar lijkt het van belang dat werkgevers zorgen voor een goed sociaal klimaat en een goede gezondheid van hun werknemers.

MAAR WAAROM WILLEN WE WEL OF NIET LANGER DOORWERKEN? Werk voorziet in allerhande behoeftes, zoals sociale contacten, een doel in het leven, waardering, geld en natuurlijk plezier. Aan de andere kant geeft vervroegd met pensioen gaan veel vrijheid en meer tijd voor bijvoorbeeld hobby's, zorgtaken en vrijwilligerswerk. Maar het is nog grotendeels onbekend wat precies de redenen zijn van werknemers om door te werken tot hun vijfenzestigste of juist eerder te stoppen met werken. In een nieuw grootschalig longitudinaal onderzoek, genaamd STREAM (Study on Transitions in Employment, Ability and Motivation), gaan we meer in op deze motivatie om te werken en de redenen om al dan niet vervroegd met pensioen te gaan.

\section{WILLEN WERKGEVERS DAT WE LANGER DOORWERKEN?}

De motivatie van werknemers om langer door te werken wordt ook beïnvloed door de mogelijkheden die werkgevers bieden. In 2008 vond slechts $22 \%$ van de werkgevers het belangrijk voor de personele bezetting van hun bedrijf dat werknemers doorwerken tot hun vijfenzestigste. Bedrijven die relatief veel ouderen in dienst hebben, hechten meer belang aan langer doorwerken. Deze bedrijven maken ook meer gebruik van instrumenten om ouderen langer in dienst te houden, zoals extra vrije dagen en taakverlichting.

\section{CONCLUSIE}

Steeds meer werknemers willen doorwerken tot hun vijfenzestigste, maar werkgevers blijven nog achter in het belang dat zij hieraan hechten en de mogelijkheden die zij hiervoor bieden. Werkgevers kunnen langer doorwerken bevorderen door bij te dragen aan een goed sociaal klimaat op het werk en aan een 
goede gezondheid van hun personeel. Dit zorgt er niet alleen voor dat werknemers langer willen doorwerken, maar ook dat zij beter in staat zijn om dat te doen.

\section{LITERATUUR}

1. Koppes L, Vroome E de, Mol M, Janssen B, Bossche S van den. Nationale Enquête Arbeidsomstandigheden 2009: Methodologie en globale resultaten. Hoofddorp: TNO, 2010.
2. Ybema JF, Geuskens G, Oude Hengel K. Oudere werknemers en langer doorwerken: Secundaire analyses van de NEA, het NEA-cohortonderzoek en de WEA. Hoofddorp: TNO, 2009.

\section{CORRESPONDENTIEADRES}

Dr. J.F. Ybema, TNO, Postbus 718, 2130 AS Hoofddorp, e-mail: jan_fekke.ybema@tno.nl

\title{
Pensionering ook sociaal bepaald
}

\author{
Kène Henkens ${ }^{1}$
}

Pensionering krijgt steeds vaker het karakter van een proces waarin mensen zich over een reeks van jaren geleidelijk van de arbeidsmarkt terugtrekken. Ook worden mensen na uittreding in toenemende mate weer actief op de arbeidsmarkt. Er zijn om langer te werken echter volop belemmeringen die moeten worden overwonnen en deze belemmeringen liggen voor een belangrijk deel op het sociale vlak.

\section{Pensionering als proces}

Nog niet zo lang geleden betekende voor de meeste mensen pensionering een abrupte overgang van een werkend naar een niet werkend leven. Pensionering betekende ook een definitief afscheid van de arbeidsmarkt. In de huidige tijd krijgt pensionering steeds vaker het karakter van een langer lopend proces waarin mensen zich over een reeks van jaren, geleidelijk van de arbeidsmarkt terugtrekken. Het is ook een dynamisch proces, in de zin dat gedurende die periode na pensionering uit de hoofdbaan nieuwe activiteiten op de arbeidsmarkt worden ontplooid. Wie de arbeidsmarktpositie van huidige zestigplussers beziet vindt een breed palet aan verschillende vormen van doorstartende gepensioneerden; als oproepkracht bij de oude werkgever, als kleine zelfstandige of gewoon in loondienst. Sommigen geven hun carrière een radicaal andere wending. Anderen gaan door met die taken van hun oude baan die de meeste bevrediging gaven. In de periode 2002 tot 2007 nam het aandeel vroeggepensioneerden dat weer actief werd op de arbeidsmarkt toe van 16 tot $23 \%$. Het percentage dat wel de ambitie heeft te werken, maar er niet in slaagt het te vinden nam ook toe: van 6 tot $10 \%$. Werk na pensioen komt weliswaar meer voor bij hoger opgeleide personen (33\%), maar ook bij lager opgeleide mensen is doorstarten met ruim $15 \%$ van de werknemers geen uitzondering meer.

\section{VERANDERENDE INSTITUTIES}

Hoe pensionering vorm krijgt kan niet los worden gezien van de bestaande en veranderende maatschappelijke en institutionele restricties. Zeker is dat de nieuwe cohorten oudere werknemers beslissingen rond werk en pensioen moeten nemen in een sterk veranderd economisch landschap. De kredietcrisis heeft de on-

1 NIDI, Den Haag en Universiteit van Tilburg, Tilburg zekerheid over de pensioenen zichtbaar gemaakt. Riante pensioeninkomens zijn geen absolute zekerheid meer. Een hogere AOW leeftijd en aanvullende pensioenen, waarin beleggingsrisico's meer dan voorheen bij individuele werknemers en gepensioneerden komen te liggen, zullen prikkelen tot langer werken. Daarnaast worden pensioenarrangementen flexibeler en staan juridische barrières die een langere arbeidsloopbaan in de weg staan, zoals een verplicht ontslag bij het bereiken van de 65-jarige leeftijd, steeds meer ter discussie.

\section{SOCIALE PRIKKELS}

Maar het wegnemen van institutionele restricties hoeft niet altijd effect te sorteren. Sociologen benadrukken dat pensionering ook afhankelijk is van de sociale context en is ingebed in de totale levensloop. Deze sociale context oefent vaak een beslissende invloed uit. Dit zien we bijvoorbeeld op het niveau van maatschappelijke normen en waarden, de arbeidsorganisatie en het huishouden. Opmerkelijk is dat het Centraal Planbureau in haar notitie "Effecten van participatiebeleid" bij het inschatten van de mogelijke gevolgen van een verhoging van de AOW-leeftijd naar 67 jaar maar een zeer geringe waarde toekent aan financiële prikkels. Men verwacht vooral een effect van een verschuivende sociaal culturele norm. Maar wat is eigenlijk de gangbare norm? Gegevens van het European Social Survey voor Nederland tonen ons een klimaat waarin langer werken niet bepaald wordt toegejuicht. Met 55 jaar met pensioen wordt weliswaar als te vroeg gezien, maar gemiddeld wordt iemand van 66 als te oud gevonden om nog 20 uur per week te werken. Een leeftijd van 61,5 geldt als ideale uittredeleeftijd.

\section{WERKGEVERS STIMULEREN LANGER WERKEN NIET}

Belemmeringen voor langer werken vinden we ook binnen arbeidsorganisaties. Op het niveau van de arbeidsorganisatie ondervinden werknemers in Nederland tot op heden weinig stimulans om langer door te werken. Het animo van werkgevers om ouderen aan te moedigen tot of na hun vijfenzestigste door te werken is nog steeds zeer gering is. En, wanneer een crisis toeslaat, steekt de roep om vervroegde pensionering weer de kop op. De afgelopen jaren trad een kwart van de werknemers gedwongen vervroegd uit simpelweg omdat de werkgever lan- 